\title{
Development of Research-Based Learning Model in Biology Education: What is Relevance, Concystency and Practicality?
}

\author{
M. Haviz \\ Department of Biology Education, Insititut Agama Islam Negeri (IAIN) Batusangkar, Indonesia
}

\begin{tabular}{|c|c|}
\hline Article Info & ABSTRACT \\
\hline Article history: & \multirow{10}{*}{$\begin{array}{l}\text { The purpose of this article is to design a consistent research-based learning } \\
\text { model and internal relevance on biology learning at Higher Education. The } \\
\text { study participants were } 88 \text { students of Biology Education Department IAIN } \\
\text { Batusangkar who studied Research Method subjects in Biology study, } \\
\text { academic year } 2016 / 2017 \text {. The method used was educational design research } \\
\text { with preliminary stages of research, prototyping stage, and assessment stage. } \\
\text { The instruments used were product assessment sheets. Preliminary research } \\
\text { findings were analysed by reducing, presenting, and drawing conclusions. } \\
\text { The mean score of formative evaluation result and mean score of the } \\
\text { students' achievement were analysed by descriptive statistic. Preliminary } \\
\text { research results showed that changes should be made toward the biology } \\
\text { learning outcomes. The next finding was that there were } 9 \text { supporting } \\
\text { theories used to design research-based learning models on biology learning. } \\
\text { Formative and summative prototype evaluation results were good and had } \\
\text { met the criteria of developing the learning model. So, it was concluded that } \\
\text { research-based learning model on biology learning had consistency and } \\
\text { internal relevance. }\end{array}$} \\
\hline Received Oct 29, 2017 & \\
\hline Revised Dec 09, 2017 & \\
\hline Accepted Jan 20, 2018 & \\
\hline Keywords: & \\
\hline Biology learning & \\
\hline Consistency & \\
\hline Internal relevance & \\
\hline Research-based learning model & \\
\hline & \\
\hline
\end{tabular}

Copyright $\left(C_{0} 2018\right.$ Institute of Advanced Engineering and Science. All rights reserved.

\section{Corresponding Author:}

M. Haviz,

Department of Biology Education

Insititut Agama Islam Negeri (IAIN) Batusangkar,

Jalan Sudirman No 137 Kuburajo Lima Kaum Batusangkar, 27213, Indonesia.

Email: mhaviz@iainbatusangkar.ac.id

\section{INTRODUCTION}

Learning in Higher Education at Indonesia should refer and apply the Indonesian National Qualification Framework-Based Learning. The Indonesian National Qualification Framework-based learning requires students to master a certain level of competence. At the undergraduate level, competencies that must be mastered by graduates are at level 7 [1]. To meet this qualification, educators must make changes to the instructional design. The changes in instructional design will affect the learning environment [2] including changes in the way of learning / teaching in the classroom. The use of specific learning models is assumed to be able to overcome various problems in learning [3].

The application of learning models is an important aspect to support biology learning [4]. The application of this model is done to test the students' understanding of the applied model [5] and to equip students with 21 st century competencies [6]. This condition requires instructional design intervention on biology learning [7].

The interventions of instructional design and change of teaching/learning at Higher Education are assumed to be undertaken by developing research-based learning models. Research-based learning on biology learning is conducted by applying scientific research and research practice [8] aimed at reducing the distance between theory and practice [9]. Both ways of learning are examples of curriculum development and teaching strategies, and also how to use the adaptive systems on instructional of [10]. The scientific research 
and research practice are conducted by teachers to develop scientific experiences by designing new learning environments [11] and using collaborative designs on lesson plans [12], cooperative learning [13], integrative learning models [14], and laboratory practical exercises [15].

When the learning model is designed, the researcher takes into account the components of the learning model such as syntax, reaction principles, social systems, support systems and impact learning [16]. The researcher also pays attention to the instructional development process as well. Instructional development can be done by adapting [17] or applying an existing learning model. The development of instructional design on biological learning should be followed by evaluation [18] and then tested to determine how it influences in learning [19].

The quality of instructional models in educational design research is determined by internal relevance and consistency aspects [20]. Both aspects are determined by the initial identification process [21], design, assessment, and revision. Formative evaluations are conducted in prototypes that have been designed to reflect the degree of product resistance toward revision [22] while documentations and systematic reflections are made in the final stages [23]. The internal relevance and consistency aspect of educational design research are also determined by the level of expectation degree toward the research findings (reality) [20]. The expectation of the results of the research toward the expected reality is proved by a series of tests such as self and expert review and used in small or large group test [22].

In this study, the researcher designed a learning model based on the learning model components written by [16]. In this study, the relevance and internal consistency of the prototype of a research-designed learning model refers to the relevance aspects and consistency that have been written by previous researchers [24]; [20] and [22]. The research question was 'how is the relevance and internal consistency in the development of research-based learning models on biology learning?' The purpose of this article was to design a consistent research-based learning model and internal relevance in biology education.

\section{RESEARCH METHOD}

The participants of this study were 88 students of Biology Education Department IAIN Batusangkar who studied Research Method subjects in Biology study, academic year 2016/2017. After conducting characteristic analysis, the participants were divided into three classes or groups of study that were class $\mathrm{A}=32$ students, class $\mathrm{B}=28$ students, and class $\mathrm{C}=28$ students.

This research was an educational design research consisting of phases: preliminary research, prototyping, and assessment [23], [24]. In preliminary stage, the researcher conducted an in-depth analysis of the issues associated with the framework based on the literature review. In the prototyping stage, the researcher designed the initial reference frame and the prototype. These activities were cyclical, and divided into three forms: design, formative evaluation, and revision. In the stage assessment, the researcher conducted a summative evaluation in the classroom for 6 meetings.

The research instruments used in this study were assessment sheets and achievement test. Preliminary research findings were analysed using Miles and Huberman techniques, namely reduction, presentation, and conclusion. The mean score of formative evaluation result were analysed by descriptive statistics [25]. Product quality was determined from the aspect of relevance and internal consistency [20]; [22].

\section{RESULTS AND ANALYSIS}

\subsection{Preliminary Stage}

The results of the preliminary stage showed that there should be changes in the learning outcomes. These changes lead to the students' competence changes in learning Research Methods in biological study. The main competencies that will be achieved after this learning process: the students are able to understand the concept of research and able to write research proposals and reports in the field of biology learning. To support the main competency goals, nine supporting competencies are required. They are (1) The students are able to explain the relationship of philosophy, research, and education; (2) The students are able to explain the basic concepts of educational research; (3) The students are able to find and select research topics; (4) The students are able to make research plan; (5) The students are able to explain how to select the research sample; (6) The students are able to design research instruments; (7) The students are able to understand, select, and conduct selected research from Descriptive Research, Correlational Research, CausalComparative Research, Experimental Research, Single-Subject Experiment, and Research Development (8) The students are able to analyse and interpret data of research result with Descriptive Statistics and Inferential Statistics, and (9) The students are able to write proposal, research report, and article to be published in scientific journal. The research findings on relevant research theories and concepts used to 
complete the prototype were listed in Table 1. Table 1 drew that there are 9 theories/concepts used to design research-based learning model prototype in biology learning.

Table 1. Theory/Concept of Development of Research-Based Learning Model on Biology Learning

\begin{tabular}{|c|c|c|}
\hline No & Theories/Concepts & \\
\hline 1 & Theory of learning [26] & $\begin{array}{l}\text { cognitivism } \\
\text { constructivism } \\
\text { behaviorism }\end{array}$ \\
\hline 2 & Construction of model [16] & $\begin{array}{l}\text { syntax } \\
\text { principle of reaction } \\
\text { system social } \\
\text { supporting system } \\
\text { instructional and nurturing effect } \\
\text { construction of model }\end{array}$ \\
\hline 3 & $\begin{array}{l}\text { Integrative model as a base of Indonesia qualification framework [14]; } \\
\text { [27]; [28] and [29] }\end{array}$ & $\begin{array}{l}\text { modern instructional } \\
\text { indonesian qualification framework } \\
\text { integrative approach }\end{array}$ \\
\hline 4 & Model based research [8] & scientific research model \\
\hline 5 & Design research and instructional design [23] & educational design research \\
\hline 6 & Subject Matter [25] & educational research \\
\hline
\end{tabular}

\subsection{Prototyping Stage}

The prototype design matrices were written in Table 2 and the logical framework was shown in Figure 1. In Table 2 the components of research-based learning models, such as development stage, construction, and model characteristics were presented. In Figure 1, there were 5 components of the model: syntax, reaction principle, social system and support system, instructional and nurturant impact.

Table 2. Prototype Matrix of Research-Based Learning Model on Biology Learning

\begin{tabular}{|c|c|c|c|c|c|c|c|c|}
\hline No & Educational & sign Research & $\begin{array}{l}\text { Model } \\
\text { Research } \\
\text { Training: } \\
\text { Model } \\
\text { Research } \\
\text { Training: } \\
\text { From Fact } \\
\text { to Theory }\end{array}$ & $\begin{array}{l}\text { Construction } \\
\text { of Model }\end{array}$ & $\begin{array}{l}\text { Behaviourism, } \\
\text { Cognitivist, } \\
\text { Constructivism }\end{array}$ & $\begin{array}{c}\text { Curriculum } \\
\text { Based } \\
\text { Competency } \\
\text { and } \\
\text { Indonesia } \\
\text { Qualification } \\
\text { Framework }\end{array}$ & $\begin{array}{c}\text { Adaptive } \\
\text { Instructional } \\
\text { System }\end{array}$ & $\begin{array}{l}\text { Material } \\
\text { of } \\
\text { Research }\end{array}$ \\
\hline 1 & $\begin{array}{l}\text { Preliminary } \\
\text { Research }\end{array}$ & $\begin{array}{l}\text { characteristic } \\
\text { of } \\
\text { instructional }\end{array}$ & $\bullet$ & $\bullet$ & $\bullet$ & $\bullet$ & $\bullet$ & $\bullet$ \\
\hline 2 & $\begin{array}{l}\text { Prototype } \\
\text { Stage }\end{array}$ & $\begin{array}{l}\text { design } \\
\text { prototype } \\
\text { formative } \\
\text { evaluation } \\
\text { Revision }\end{array}$ & $\bullet$ & $\bullet$ & $\bullet$ & $\bullet$ & $\bullet$ & • \\
\hline 3 & $\begin{array}{l}\text { Assessment } \\
\text { Stage }\end{array}$ & $\begin{array}{l}\text { summative } \\
\text { evaluation }\end{array}$ & $\bullet$ & $\bullet$ & $\bullet$ & $\bullet$ & • & $\bullet$ \\
\hline
\end{tabular}

Note: Abs $(\bullet)$ show the component on matrix

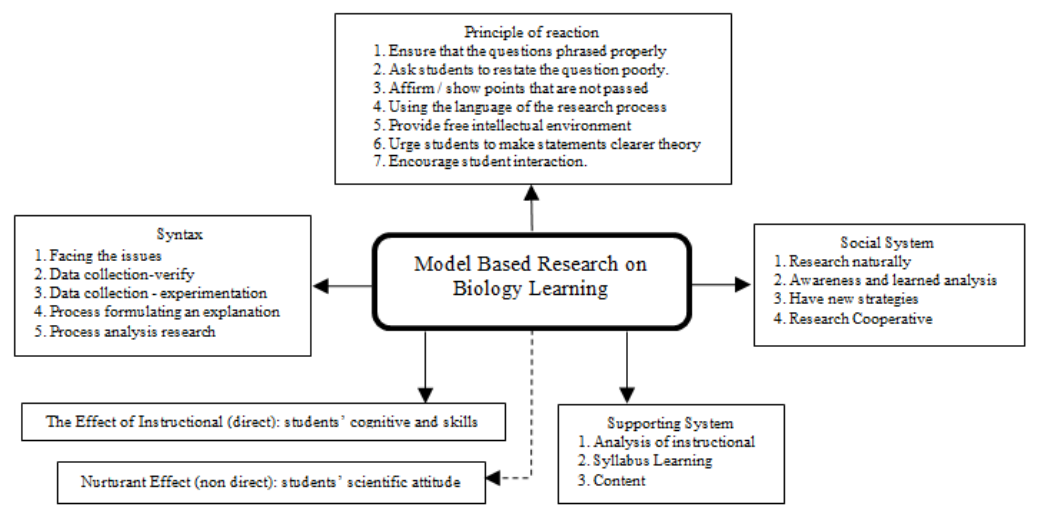

Figure 1. Logical framework model of research-based learning on biology learning 
Formative evaluation results were described in Table 3. It showed that the prototype obtained a valid value. Several revisions that have been made to improve the prototype of reducing the characteristics that would be used for designing and clarifying the syntax of learning to be used during the summative evaluation.

Table 3. Scores of Formative Evaluation Results of Research-Based Learning Models on Biology Learning

\begin{tabular}{|c|c|c|c|c|c|c|}
\hline \multirow[b]{2}{*}{ No } & \multirow[b]{2}{*}{ Aspect } & \multirow[b]{2}{*}{ Indicator } & \multicolumn{4}{|c|}{ Result evaluation } \\
\hline & & & $\begin{array}{c}\text { Poor } \\
(\mathrm{M} \pm \mathrm{STDEV})\end{array}$ & $\begin{array}{c}\text { Fair } \\
(\mathrm{M} \pm \mathrm{STDEV})\end{array}$ & $\begin{array}{c}\text { Good } \\
(\mathrm{M} \pm \mathrm{STDEV})\end{array}$ & $\begin{array}{c}\text { Very Good } \\
(\mathrm{M} \pm \text { STDEV })\end{array}$ \\
\hline \multirow{3}{*}{1} & \multirow{3}{*}{ Construction } & theory of learning & $0,00 \pm 0,00$ & $0,00 \pm 0,00$ & $3,00 \pm 4,24$ & $0,00 \pm 0,00$ \\
\hline & & learning model & $0,00 \pm 0,00$ & $0,00 \pm 0,00$ & $3,00 \pm 8,49$ & $0,00 \pm 0,00$ \\
\hline & & design research & $0,00 \pm 0,00$ & $0,00 \pm 0,00$ & $0,00 \pm 0,00$ & $4,00 \pm 8,49$ \\
\hline \multirow{4}{*}{2} & \multirow{4}{*}{ Characteristic } & \multirow{3}{*}{$\begin{array}{l}\text { learning based research } \\
\text { modern instructional } \\
\text { curriculum based } \\
\text { competency and } \\
\text { Indonesian national } \\
\text { qualification framework }\end{array}$} & $0,00 \pm 0,00$ & $0,00 \pm 0,00$ & $3,00 \pm 8,49$ & $0,00 \pm 0,00$ \\
\hline & & & $0,00 \pm 0,00$ & $0,24 \pm 2,66$ & $1,94 \pm 21,96$ & $0,88 \pm 9,98$ \\
\hline & & & $0,00 \pm 0,00$ & $0,00 \pm 0,00$ & $1,00 \pm 5,66$ & $2,67 \pm 15,09$ \\
\hline & & $\begin{array}{l}\text { adaptive instructional } \\
\text { system }\end{array}$ & $0,00 \pm 0,00$ & $0,4 \pm 1,13$ & $1,8 \pm 5,09$ & $0,8 \pm 2,27$ \\
\hline 3 & \multirow{2}{*}{\multicolumn{2}{|c|}{$\begin{array}{l}\text { Content } \\
\text { Indonesian language }\end{array}$}} & $0,00 \pm 0,00$ & $0,00 \pm 0,00$ & $3,00 \pm 0,00$ & $0,00 \pm 0,00$ \\
\hline 4 & & & $0,00 \pm 0,00$ & $0,00 \pm 0,00$ & $3,00 \pm 0,00$ & $0,00 \pm 0,00$ \\
\hline
\end{tabular}

\subsection{Assesment Stage}

The result of practical/effectiveness test is written on the the Table 4. The final results of student learning that indicates the level of practicality prototype was 38.34 \pm 9.77 (very practice); $33.89 \pm 9: 06$ (practice); 22:31 \pm 9:18 (less practice) and 5:46 \pm 0.80 (no practice). The results showed the intervention could be used in a setting that has been designed and developed. These results are supported after syntax, the principle of reaction, the social system and learning models is applied. The results also showed the expected intervention has provided the actual results. These results are supported by the good results of student learning after the learning process is done. The results showed the intervention could be used in a setting that has been designed and developed. These results are supported after syntax, the principle of reaction, the social system and learning models is applied. The results also showed the expected intervention has provided the actual results. These results are supported by the good results of student learning after the learning process is done.

Table 4. Formative Evaluation Score Based on Achievement of Student Learning Outcomes After the Application of Research-Based Learning Model on Biology Learning

\begin{tabular}{|c|c|c|c|c|c|c|c|c|c|c|c|c|}
\hline \multirow{3}{*}{ No } & \multicolumn{11}{|c|}{ Students Achievement } & \multirow{3}{*}{$\begin{array}{c}\text { The level } \\
\text { of product } \\
\text { goodness } \\
\text { value after } \\
\text { used }\end{array}$} \\
\hline & \multicolumn{2}{|c|}{ Criteria } & \multicolumn{3}{|c|}{ Cognitive } & \multicolumn{3}{|c|}{ Skill } & \multicolumn{3}{|c|}{ Attitude } & \\
\hline & Score & Quality & $\sum$ & M & STDEV & $\sum$ & M & STDEV & $\Sigma$ & M & STDEV & \\
\hline 1 & $85-100$ & A & 27 & 30.68 & 2.60 & 18.25 & 20.75 & 1.76 & 14 & 15.90 & 1.35 & \multirow{2}{*}{$\begin{array}{l}\text { Very } \\
\text { Good }\end{array}$} \\
\hline 2 & $80-84$ & A- & 18 & 20.45 & 1.73 & 14.25 & 16.23 & 1.40 & 9.66 & 10.98 & 0.93 & \\
\hline 3 & $75-79$ & $\mathrm{~B}+$ & 20 & 22.73 & 1.92 & 25.75 & 29.40 & 16.1 & 21.33 & 24.24 & 2.05 & \multirow{2}{*}{ Good } \\
\hline 4 & $70-74$ & B & 9 & 10.23 & 0.86 & 10.5 & 12.01 & 6.01 & 2.66 & 3.03 & 0.25 & \\
\hline 5 & $65-69$ & B- & 6 & 6.81 & 0.57 & 14 & 16.14 & 3.59 & 16.33 & 18.56 & 1.57 & \multirow{3}{*}{ Fair } \\
\hline 6 & $60-64$ & $\mathrm{C}+$ & 4 & 4.54 & 0.38 & 1.5 & 1.73 & 0.68 & 7 & 5.68 & 0.48 & \\
\hline 7 & $55-59$ & $\mathrm{C}$ & 3 & 3.40 & 0.28 & 1.5 & 1.71 & 0.93 & 7.33 & 8.33 & 0.70 & \\
\hline 8 & $45-54$ & D & 0 & 0 & 0 & 0 & 0 & 0 & 2.66 & 3.03 & 0.25 & \multirow{2}{*}{ Poor } \\
\hline 9 & $<45$ & $\mathrm{E}$ & 1 & 1.13 & 0.09 & 1.75 & 2.01 & 1.21 & 9 & 10.22 & 0.86 & \\
\hline
\end{tabular}


The research findings show that the design and development model based research on biology learning that has been done based on the theory of learning. Some theories of learning are used as the based for the development of instructional design are cognitive, behavioristic and constructivist. There are several arguments to describe the relationship of learning theory and its implications for learning. First, learning theory contribute to improving the structure of concepts that underlie the process of providing information and stored in long term memory and can be called back in the observation of student achievement [30]. Second, the theory of learning will improve learning strategies, tactics and behavior supported by the theory. For example, on the model of instructional systems design designers make use of theories of learning and their learning strategies in the design phase. Third, there are many ways in the design and development of the structure of matter, such as the individual materials, modules, units of learning appropriate to the subject that is always used and based on one or more learning theory. Instructional systems design design phase is influenced by behaviorism, cognitivist and constructivism the results of the research [31]. In other study has integrating objectivistic and constructivist learning in instructional design [32]. These findings showed that prototypes of research-based learning models were supported by good empirical data. So, this study that the prototype has good value on the content and construct validity aspects (content and construct validity). The findings also exposed that there was a logical intervention so that the prototype had a state-of-the-art (scientific) knowledge.

The results of assessment stage showed that there was an instructional impact from prototype intervention which designed, and the process of applying the 5 components of the research-based learning model ie syntax, reaction principle, social system, and support system. The impact of such instruction was the excellent score of student learning outcomes. These results showed that the expected outcomes before the intervention were performed in accordance with the results found after the intervention. These explanations described that research-based learning models on biological learning met internal relevance criteria and consistency. The internal relevance and consistency aspect of the research development was determined by the extent of expectation with the findings of research (reality) [20]. The expectation of the results of the research toward the expected reality was proved by a series of evaluations such as self and expert review and application test used in small or large group test [22]. So the findings of this study met important aspects in educational design research [23] or/and research and development [21].

Model based research on biology learning also show that the fulfillment of the important aspects in the educational design resdearch. Some of the arguments supporting this statement are described in the following sections. First, the research findings show that the systematic process starting from the design, development, program evaluation and learning products and meet the criteria of internal consistency and effectiveness of the use of the program or product [33]. Second, this research has resulted in products such as the learning model that write to the concept, and deafened summarized in chart. These results are similiarity with the explanation by others researcher, the research design is the study systematically the process of designing, developing and evaluating the "intervention" (such as programs, strategies of teaching-learning along with their devices, products, and systems) as a solution to the complex problem in practical education, and also aims to increase knowledge of the characteristics of an "intervention" and the design and development process [23]. Third, model based research on biology learning begins with curriculum development. These findings are indicate that research and development can be done to develop the curriculum, media and technology, teaching and learning and teacher education and didactic, which is presented in two types of formative research and reconstructive research [34]. Fourth, model based research on biology learning will be used for learning policy development at the sites, because research and development is closely connected with education professionals, including for policy in the field of education. The aim is to develop research based on the discovery of a solution to the complex problems in the field of education. Because the process and the results of research, such as innovating learning model will determine the direction and purpose of the development of the educational process, and useful for the development of the institution [23].

The result also shows that model based research on biology learning that has been designing and developing have competence, learning objectives and characteristics of learners. Model based research on biology learning contains competence and capability in the completion of the task. Because of competence shown by the capabilities of task completion with results that are in scale between good and excellent. This conclusion was obtained after a study of characteristics of competencies are combination of cognitive, skill and attitude and performance up to the level of good or very good [27]. Similiarity with this statement, model based research on biology learning that has been designing and developing also linked to the Indonesian qualifications framework. The impact of Indonesian qualifications framework are (1) increasing the quantity of Indonesian human resources quality and international competitiveness in order to ensure an increase in the accessibility of Indonesian human resources to the labor market; (2) increase the contribution of learning outcomes obtained formal education, non-formal, informal or work experience in the growth of the national economy; (3) increased academic mobility to promote mutual understanding and solidarity and cooperation

Development of Research-Based Learning Model in Biology Education: What is Relevance, ...(M. Haviz) 
of higher education and countries in the world and (4) increasing recognition of other countries bilaterally, regionally and internationally to Indonesia without leaving the character and personality of Indonesia [28].

\section{CONCLUSION}

Research-based learning model on biology learning has internal consistency and relevance. It has been developed based on state-of-the-art (scientific) knowledge, a number of good theories; so that the product has good content and construct validity. In conclusion, the expected product (expectation) is in accordance with the product produced (actual). However, the product of this study requires a wide-scale test of implementation to increase its resistance to revision.

\section{ACKNOWLEDGEMENTS}

This research was funded by DIPA of Institut Agama Islam Negeri (IAIN) Batusangkar in accordance with the research contract Number B-213/ln.27/L.1/TL.00/06/2016 dated June $15^{\text {th }}, 2016$. The researcher expressed his gratitude to the institution for financing this research. The researcher also expressed his thanks to all those who have assisted in conducting this research.

\section{REFERENCES}

[1] Regulation of the Minister of Education and Culture of the Republic of Indonesia No. 73 year 2013.

[2] I. J. Choi and M. Hannafin, "Situated cognition and learning environments: roles, structures, and implications for design," Educational Technology Research and Development, vol. 43, no. 2, pp. 53-69, 1995.

[3] A. Isman, "An instructional design in education: new model," The Turkish Online Journal of Educational Technology, vol. 10, no. 1, pp. 136-142, 2011.

[4] M. Krell and D. Krüger, "Testing models: a key aspect to promote teaching activities related to models and modelling in biology lessons?," Journal of Biological Education, vol. 50, no. 2, pp. 160-173, 2016.

[5] J. Grünkorn, A. U. z. Belzen and D. Kruger, "Assessing Students' Understandings of Biological Models and their Use in Science to Evaluate a Theoretical Framework," International Journal of Science Education, pp. 1651-1684, 2014.

[6] L. Greenstein, Assesing 21st Century Skill. a Guide to Evaluating Mastery and Authentic Learning, California: SAGE Company, 2012.

[7] F. Janssen and A. J. Waarlo, "Learning biology by designing," Journal of Biological Education, vol. 44, no. 2, pp. 88-92, 2010.

[8] B. R. Joyce, M. Weil and E. Calhoun, Models of Teaching, 9th ed., Allyn and Bacon Publisher, 2009.

[9] R. V. \&. J. v. B. Vanderlinde and J. v. Braak, "The gap between educational research and practice: views of teachers, school leaders, intermediaries and researchers," British Educational Research Journal, vol. 36, no. 2, pp. 299-316, 2010.

[10] M. Haviz, "Modern instructional design on educational research: how to use the adaptive systems on instructional of biology," in International Conference on Mathematics, Science, Education and Technology (ICOMSET), Padang, 2015.

[11] C. L. Stuessy and J. S. Metty, "The learning research cycle: bridging research and practice," Journal of Science Teacher Education, vol. 18, no. 5, pp. 725-750, 2007.

[12] N. N. P. Roblin, B. J. Ormel, S. E. McKenney, J. M. Voogt and J. M. Pieter, "Linking research and practice through teacher communities: a place where formal and practical knowledge meet?," European Journal of Teacher Education, vol. 37, no. 2, pp. 183-203, 2014.

[13] M. Haviz, "Cooperative learning model on developmental of biology," American Journal Educational Research, vol. 3, no. 10, pp. 1298-1304, 2015.

[14] M. Haviz, Lufri, A. Fauzan and Z. M. Efendi, "Pengembangan model pembelajaran integratif pada biologi perkembangan hewan: analisis kebutuhan pengembangan," Ta'dib, vol. 15, no. 1, pp. 1-14, 2012.

[15] A. M. Osuafor and I. A. Amaefuna, "A survey of biology teachers use of activity-oriented, laboratory practical exercises to promote functional biology education," Journal of Education and Learning, vol. 10, no. 3, pp. 281290, 2016.

[16] B. R. Joyce and M. Weil, Models of Teaching, 4th ed., Massachusetts: Allyn and Bacon Publisher, 1992.

[17] C. O. Park and J. Lee, "Adaptive Instructional System," in Handbook of Research on Educational Communications and Technology (2nd Edition), 2nd ed., 2002, pp. 1101-1130.

[18] M. Ummels, M. Kamp, H. d. Kroon and K. T. Boersma, "Designing and evaluating a context-based lesson sequence promoting conceptual coherence in Biology," Journal of Biological Education, vol. 49, no. 1, pp. 38-52, 2015.

[19] M. S. Koksal, J. Cakiroglu and O. Geban, "The effect of explicit embedded reflective instruction on nature of science understandings in advanced science students," Journal of Biological Education, vol. 47, no. 4, pp. 208-223, 2013. 
[20] N. Nieeven, "Formative Evaluation in Educational Design Research," in An Introduction to Educational Design Research, T. Plomp and N. Nieeveen , Eds., SLO - Netherlands Institute for Curriculum Development, 2010, pp. 91-115.

[21] R. C. Richey, J. D. Klein and W. A. Nelson, "Developmental Research: Studies of Instructional Design and Development," in Handbook of Research on Educational Communications and Technology, D. Jonassen, Ed., Washington, Association for Educational Communication and Technology, 2002, p. 1101.

[22] M. Tessmer, Planning and Conducting Formative Evalution, London: Kogan Page, 1993.

[23] T. Plomp, "Educational Design Research: An Introduction," in An Introduction to Educational Design Research, T. Plomp and N. Nieeveen, Eds., Netherlands, 2010, pp. 9-35.

[24] M. Haviz, "Research and development; penelitian di bidang kependidikan yang inovatif, produktif dan bermakna," Ta'dib, vol. 16, no. 1, pp. 28-42, 2013.

[25] L. R. Gay, G. E. Mills and P. W. Airasian, Educational Research, Competencies for Analysis and Application, 9th ed., New Jersey: Pearson Education., 2009.

[26] P. A. Ertmer and T. J. Newby, "Behaviorism, cognitivism and constructivism: comparing critical features from an instructional design perspective," Performance Improvement Quarterly, vol. 6, no. 4, pp. 43-71, 2013.

[27] A. Suparman, Desain Instruksional Modern, Jakarta: Penerbit Erlangga, 2012.

[28] Direktorat Jenderal Pendidikan Tinggi, Kementerian Pendidikan dan Kebudayaan, 2011.

[29] S. M. Drake and R. C. Burns, Integrated Curriculum, Meeting Standards Through, Virginia USA: Association for Supervision and Curriculum Development, 2004.

[30] R. M. Gagné, W. W. Wager, K. C. Golas and J. M. Kell, Principles of Instructional Design, 5th ed., Belmont, CA: Thomson/Wadsworth, 2005.

[31] D. L. Sink, "Instructional Design Models and Learning Theories," USA, American Society for Training \& Development, 2014.

[32] J. Cronje, "Paradigms regained: toward integrating objectivism and constructivism in instructional design and the learning sciences," Education Tech Research Dev, vol. 54, no. 4, pp. 387-416, 2006.

[33] B. B. Seels and R. C. Richey, Instructional Technology: The definition and Domains of the Field, Washington: Association for Educational Communications and Technology, 1994, p. 127.

[34] J. V. d. Akker, "Principles and Methods of Development Research," in Design Approaches and Tools in Education and Training, T. Plomp, N. Nieveen, K. Gustafson, R. M. Branch and J. V. d. Akker, Eds., London, Kluwer Academic Publisher, 1999, pp. 3-9.

\section{BIOGRAPHY OF AUTHOR}

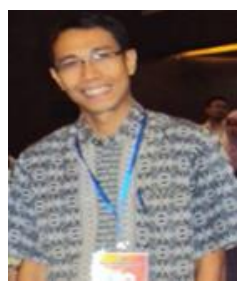

M. Haviz is PhD, Master of Science.

Assistant Professor at Department Biology of Education IAIN Batusangkar.

Jalan Sudirman No. 137 Kubu Rajo Lima Kaum Batusangkar, Wes Sumatra, Indoenesia. E-mail: mhaviz@iainbatusangkar.ac.id; Website: http://www.iainbatusangkar.ac.id

Interest research: science education, biology education, teaching and learning strategy, educational design research and empowerment of indigenous minangkabau 